\title{
Simultaneous Loss of NCKX4 and CNG Channel Desensitization Impairs Olfactory Sensitivity
}

\author{
(1)Christopher H. Ferguson and 1 Haiqing Zhao \\ Department of Biology, Johns Hopkins University, Baltimore, Maryland, 21218
}

In vertebrate olfactory sensory neurons $(\mathrm{OSN}), \mathrm{Ca}^{2+}$ plays key roles in both mediating and regulating the olfactory response. $\mathrm{Ca}^{2+}$ enters OSN cilia during the response through the olfactory cyclic nucleotide-gated (CNG) channel and stimulates a depolarizing chloride current by opening the olfactory $\mathrm{Ca}^{2+}$-activated chloride channel to amplify the response. $\mathrm{Ca}^{2+}$ also exerts negative regulation on the olfactory transduction cascade, through mechanisms that include reducing the CNG current by desensitizing the CNG channel via $\mathrm{Ca}^{2+} /$ calmodulin (CaM), to reduce the response. $\mathrm{Ca}^{2+}$ is removed from the cilia primarily by the $\mathrm{K}^{+}$-dependent $\mathrm{Na}^{+} / \mathrm{Ca}^{2+}$ exchanger 4 (NCKX4), and the removal of $\mathrm{Ca}^{2+}$ leads to closure of the chloride channel and response termination. In this study, we investigate how two mechanisms conventionally considered negative regulatory mechanisms of olfactory transduction, $\mathrm{Ca}^{2+}$ removal by NCKX4, and desensitization of the $\mathrm{CNG}$ channel by $\mathrm{Ca}^{2+} / \mathrm{CaM}$, interact to regulate the olfactory response. We performed electro-olfactogram (EOG) recordings on the double-mutant mice, $N C K X 4^{-/-} ; C N G B 1^{\Delta C a M}$, which are simultaneously lacking NCKX $\left(\mathrm{NCKX}^{-/-}\right)$and $\mathrm{Ca}^{2+} / \mathrm{CaM}^{-}$ mediated CNG channel desensitization $\left(C N G B 1^{\Delta C a M}\right)$. Despite exhibiting alterations in various response attributes, including termination kinetics and adaption properties, $\mathrm{OSN}$ s in either $\mathrm{NCKX}^{-/-}$mice or $\mathrm{CNGB1}^{\mathrm{\Delta CaM}}$ mice show normal resting sensitivity, as determined by their unchanged EOG response amplitude. We found that OSNs in $\mathrm{NCKX}^{-/-} ; \mathrm{CNGB}^{\Delta \mathrm{CaM}}$ mice displayed markedly reduced EOG amplitude accompanied by alterations in other response attributes. This study suggests that what are conventionally considered negative regulatory mechanisms of olfactory transduction also play a role in setting the resting sensitivity in OSNs.

Key words: calcium regulation; $\mathrm{CNG}$ channel; olfactory adaptation; olfactory transduction; sensitivity; sodium-calcium exchanger

\section{Significance Statement}

Sensory receptor cells maintain high sensitivity at rest. Although the mechanisms responsible for setting the resting sensitivity of sensory receptor cells are not well understood, it has generally been assumed that the sensitivity is set primarily by how effectively the components in the activation cascade of sensory transduction can be stimulated. Our findings in mouse olfactory sensory neurons suggest that mechanisms that are primarily responsible for terminating the olfactory response are also critical for proper resting sensitivity.

\section{Introduction}

In vertebrate olfactory sensory neurons (OSNs), $\mathrm{Ca}^{2+}$ plays dual but opposing roles in the signaling cascade by mediating both the activation and the negative regulation of olfactory transduction (Matthews and Reisert, 2003), a process by which OSNs convert

\footnotetext{
Received Aug. 9, 2016; revised 0ct. 24, 2016; accepted Nov. 4, 2016.

Author contributions: C.H.F. and H.Z. designed research; C.H.F. performed research; C.H.F. and H.Z. analyzed data; C.H.F. and H.Z. wrote the paper.

This work was supported by National Institutes of Health Grant DC007395 to H.Z. C.H.F. was supported in part by National Institutes of Health Training Grant T32GM007231. We thank Drs. Crystal Wall, Johannes Reisert, Samer Hattar, Kyle Cunningham, and Rejji Kuruvilla for critical discussion and suggestions; and members of the H.Z., Hattar, and Kuruvilla laboratories for discussion.

The authors declare no competing financial interests.

Correspondence should be addressed to Dr. Haiqing Zhao, Department of Biology, Johns Hopkins University, Baltimore, MD 21218. E-mail: hzhao@jhu.edu.

DOI:10.1523/JNEUROSCI.2527-16.2016

Copyright $\odot 2017$ the authors $\quad 0270-6474 / 17 / 370110-10 \$ 15.00 / 0$
}

odor stimulation into membrane depolarization. Transduction occurs in the cilia of OSNs and is initiated when odor molecules in the environment bind to odorant receptors (ORs) and stimulate the generation of the second messenger cAMP. cAMP activates the olfactory cyclic nucleotide-gated (CNG) cation channel and promotes influx of $\mathrm{Ca}^{2+}$ and $\mathrm{Na}^{+}$into the cilia, resulting in the initial depolarization. $\mathrm{Ca}^{2+}$ in the cilia triggers a depolarizing $\mathrm{Cl}^{-}$current by stimulating the $\mathrm{Ca}^{2+}$-activated chloride channel, Anoctamin 2 (ANO2) (for review, see Firestein, 2001; Kleene, 2008; Kaupp, 2010; Ferguson and Zhao, 2016), thus amplifying the olfactory response. $\mathrm{Ca}^{2+}$ in the cilia, in addition to amplifying the response, also negatively feeds back onto the transduction cascade leading to a reduction in response size during sustained or in response to recurring odor stimulation, a phenomenon known as adaptation (Torre et al., 1995; Zufall and LeindersZufall, 2000). This $\mathrm{Ca}^{2+}$-mediated feedback can inhibit many of the activation processes of transduction, including cAMP pro- 
duction (Wayman et al., 1995; Wei et al., 1996, 1998), cAMP accumulation (Firestein et al., 1991; Boekhoff and Breer, 1992; Cygnar and Zhao, 2009), and CNG channel activation (Liu et al., 1994; Bradley et al., 2001, 2004; Munger et al., 2001; Song et al., 2008).

Given the dual importance of $\mathrm{Ca}^{2+}$ in olfactory transduction, tight regulation of $\mathrm{Ca}^{2+}$ levels in the cilia is critical for proper olfactory function. $\mathrm{Ca}^{2+}$ is extruded from cilia primarily by the $\mathrm{K}^{+}$-dependent $\mathrm{Na}^{+} / \mathrm{Ca}^{2+}$ exchanger 4 (NCKX4) (Reisert and Matthews, 1998; Stephan et al., 2011). $\mathrm{Ca}^{2+}$ removal leads to closure of the chloride channel and repolarization of the membrane, thereby priming OSNs for the next odor stimulation. The influx of $\mathrm{Ca}^{2+}$ can be reduced by $\mathrm{Ca}^{2+}$-mediated feedback via calmodulin (CaM) onto the CNG channel, which desensitizes the CNG channel to cAMP (Liu et al., 1994; Bradley et al., 2001, 2004; Munger et al., 2001). Binding of $\mathrm{Ca}^{2+} / \mathrm{CaM}$ to the CNG channel reduces not only the influx of $\mathrm{Ca}^{2+}$, but also the depolarizing CNG channel current. Because extrusion of $\mathrm{Ca}^{2+}$ results in response termination and CNG channel desensitization reduces CNG current, these regulatory mechanisms are conventionally considered negative regulatory mechanisms of olfactory transduction.

Previously, we investigated the individual contribution of $\mathrm{Ca}^{2+}$ extrusion through NCKX4 and desensitization of the CNG channel by $\mathrm{Ca}^{2+} / \mathrm{CaM}$ to olfactory transduction. OSNs in mice that lack NCKX4, referred to henceforth as $\mathrm{X} 4^{-1-}$ mice, display a substantially prolonged termination phase of the olfactory response, less response decay during sustained odor stimulation, and enhanced-adaptation to repeated stimulation (Stephan et al., 2011). Deletion of the CaM-binding site on the B1b subunit of the CNG channel renders the channel insusceptible to $\mathrm{Ca}^{2+}$ / CaM-mediated desensitization (Bradley et al., 2004; Song et al., 2008). OSNs in mice that lack the CaM-binding site on the B1b subunit, referred to henceforth as $\mathrm{B} 1^{\Delta \mathrm{CaM}}$ mice, display prolonged response termination and less response decay during sustained odor stimulation, but little defect in adaptation to repeated stimulation (Song et al., 2008). Notably, OSNs in neither $\mathrm{X} 4^{-1-}$ mice nor $\mathrm{B} 1^{\triangle \mathrm{CaM}}$ mice exhibit changes in resting sensitivity (Song et al., 2008; Stephan et al., 2011). Here, we use the term sensitivity to refer to the amplitude of the electroolfactogram (EOG) response to a given odorant concentration.

We sought to investigate how these two regulatory mechanisms $\left(\mathrm{Ca}^{2+}\right.$ extrusion through NCKX4 and desensitization of the $\mathrm{CNG}$ channel by $\mathrm{Ca}^{2+} / \mathrm{CaM}$ ) interact to regulate the olfactory response. Remarkably, we observed that $\mathrm{X} 4^{-1-} ; \mathrm{B} 1^{\Delta \mathrm{CaM}}$ mice displayed markedly reduced EOG amplitudes, suggesting that what are conventionally considered negative regulatory mechanisms play a role in setting the resting sensitivity in OSNs.

\section{Materials and Methods}

Animals. For all experiments involving mice, the animals were handled and killed in accordance with methods approved by the Animal Care and Use Committees of Johns Hopkins University. All analyses involving animals were performed on adult (2-6 months old) mice. Experiments were performed on both male and female mice.

EOG recording. EOG recording was performed essentially as described previously (Cygnar et al., 2010). The mouse was killed by $\mathrm{CO}_{2}$ asphyxiation and decapitated. The head was cut sagittally to expose the medial surface of the olfactory turbinates. The recording electrode, a $\mathrm{Ag}-\mathrm{AgCl}$ wire in a capillary glass pipette filled with Ringer's solution $(135 \mathrm{~mm}$ $\mathrm{NaCl}, 5 \mathrm{~mm} \mathrm{KCl}, 1 \mathrm{~mm} \mathrm{CaCl}_{2}, 1.5 \mathrm{~mm} \mathrm{MgCl}_{2}$, and $10 \mathrm{~mm}$ HEPES, pH 7.4) containing a $0.5 \%$ agarose plug at the tip, was placed on the surface of the olfactory epithelium and connected to a differential amplifier (DP-301, Warner Instruments). EOG signals were recorded from the surface of turbinate IIB and acquired with AxoGraph software (Molecular Devices, RRID: SCR_014284) on a Macintosh computer. The signals were lowpass filtered at $1 \mathrm{kHz}$ and recorded at a sampling rate of $2 \mathrm{kHz}$. The recorded signals were further low-pass filtered at $25 \mathrm{~Hz}$ during analysis. Data were then exported from AxoGraph and analyzed in MATLAB (MathWorks, RRID: SCR_001622). Odorant solutions were prepared as either $0.05 \mathrm{~m}$ (heptaldehyde) or $1 \mathrm{~m}$ (amyl acetate) stocks in DMSO and then diluted with water to the indicated concentrations used for stimulation. Vapor-phase odorant stimuli were generated by placing $5 \mathrm{ml}$ of odorant solution in a sealed $60 \mathrm{ml}$ glass bottle. This vapor was delivered by a Picospritzer (Parker Hannifin) as a pulse injected into a continuous stream of humidified air flowing over the tissue sample. All EOG recordings were conducted at room temperature. Values for the odorant concentration of half-maximal response were calculated by fitting response amplitude data to a dose-response ( $\log$ (agonist) vs response) model with variable slope in Prism 6.0 (GraphPad Software). (Because the exact odorant concentration of the vapor phase in each stimulation bottle is not known, fitting of the dose-response relation can be affected by this fact and may not be accurate.) For analysis of the termination phase of the response to a single brief pulse, the integration time windows were from the peak time to a time beyond the peak determined by the stimulus concentration. The integration time beyond the peak was $2 \mathrm{~s}$ for $10^{-7} \mathrm{M}$ and $10^{-6} \mathrm{M}, 3 \mathrm{~s}$ for $10^{-5}$, and $10 \mathrm{~s}$ for $10^{-4}-0.05 \mathrm{M}$ heptaldehyde. For analysis of paired-pulse responses, because the response to the first odorant pulse had not returned to baseline at the time the second pulse is given, the "net" peak amplitude to the second response was determined by measuring the size of the response at the time of presentation for the second stimulus and subtracting that value from the second pulse peak amplitude. The paired-pulse adaptation was quantified by taking the ratio of the net second response peak relative to the first response peak.

Western blotting. The olfactory epithelium was dissected and homogenized in cell lysis buffer ( $1 \%$ NP40, $0.5 \%$ Na deoxycholate, $0.1 \%$ SDS, 1 mM EDTA, 1 mM EGTA in $\mathrm{dH}_{2} \mathrm{O}$ ) and stored at $-80^{\circ} \mathrm{C}$ until use. Homogenates were then resuspended in $2 \times$ Lamelli buffer and subjected to SDS-PAGE followed by transfer onto a PVDF membrane. Membranes were incubated with blocking buffer $(5 \%(\mathrm{w} / \mathrm{v})$ nonfat dry milk in TBST (20 mm Tris, $150 \mathrm{~mm} \mathrm{NaCl}$, and $0.1 \%(\mathrm{v} / \mathrm{v})$ Tween 20$)$ ) for $1 \mathrm{~h}$ at room temperature and then incubated overnight at $4^{\circ} \mathrm{C}$ with primary antibodies at respective dilutions in blocking buffer. Membranes were then washed with TBST followed by incubation with secondary antibodies conjugated to HRP in blocking buffer for $1 \mathrm{~h}$ at room temperature. The blot was visualized with Western Lightning Plus-ECL, Enhanced Chemiluminescent Substrate (Perkin Elmer, NEL103001EA) with detection on BluRay HS Autoradiography Film (Next Day Science). Band density was quantified using ImageJ (National Institutes of Health). Primary antibodies were used at the following dilutions: anti-AC3 (Santa Cruz Biotechnology, SC-588, RRID: AB_630839), 1:2000; anti-CNGA2 (Alomone Labs, APC-045, RRID: AB_2039820), 1:200; anti- $\alpha$-tubulin (Sigma, T8203, RRID: AB_1841230), 1:10,000; anti- $\beta$-actin (Cell Signaling Technology, 4970L, RRID: AB_2223169), 1:5000; anti-olfactory marker protein (OMP) (Wako, 019-22291, RRID: AB_664696), 1:10,000; and anti-GAP43 (EMD Millipore, AB5220, RRID: AB_21 07282), 1:4000. Densitometry was performed using ImageJ analysis software (National Institutes of Health).

Immunostaining. Mice were deeply anesthetized by tribromoethanol (Avertin) and then perfused transcardially with $1 \times$ PBS followed by $4 \%$ $(\mathrm{w} / \mathrm{v})$ PFA. Olfactory tissues were dissected and postfixed overnight at $4^{\circ} \mathrm{C}$, followed by decalcification in $250 \mathrm{~mm}$ EDTA for $5 \mathrm{~d}$, and then cryoprotection in $30 \%(\mathrm{w} / \mathrm{v})$ sucrose overnight at $4^{\circ} \mathrm{C}$. We cut $14-\mu \mathrm{m}-$ thick cryosections and stored them at $-80^{\circ} \mathrm{C}$. Tissue sections were incubated overnight at $4^{\circ} \mathrm{C}$ with primary antibodies in $1 \times$ PBS containing $0.1 \%(\mathrm{v} / \mathrm{v})$ Triton X-100 and $1 \%(\mathrm{v} / \mathrm{v})$ normal donkey serum. After washing, the sections were incubated with secondary antibodies conjugated to Alexa-488, Alexa-546, Alexa-555, or Alexa-647 (Invitrogen) and imaged by confocal microscopy (LSM 700, Zeiss). Primary antibodies were used at the following dilutions: anti-ACIII (Santa Cruz Biotechnology, SC-588, RRID: AB_630839), 1:200; anti-CNGA2 (Alomone Labs, APC-045, RRID: AB_2039820), 1:200; anti-OMP (Wako, 019-22291, RRID: AB_664696), 1:400; and anti-acetylated tubulin (Sigma, T7451, 
RRID: AB_609894), 1:400. Percent OMP-positive cells in the olfactory epithelium was calculated by dividing the number of OMP-positive cells by the total number of DAPI-stained nuclei in a single $z$-plane image from a $200 \mu \mathrm{m}$ length of septal epithelium. OMP-positive cell analysis was done on $3 \mathrm{WT}$ and $3 \mathrm{X} 4^{-1-} ; \mathrm{B} 1^{\Delta \mathrm{CaM}}$ mice with 5 areas analyzed per animal.

\section{Results}

To analyze the influence of both CNG channel desensitization and $\mathrm{Ca}^{2+}$ extrusion on olfactory response, we recorded EOG from X4 ${ }^{-1-} ; \mathrm{B} 1^{\Delta \mathrm{CaM}}$ mice (Scott and Scott-Johnson, 2002; Cygnar et al., 2010). The EOG is the negative potential recorded at the surface of the olfactory epithelium resulting primarily from the summed receptor potentials of OSNs (Scott and Scott-Johnson, 2002). It serves as a convenient and reliable measurement to evaluate OSN physiology and the impact of olfactory mutations. We first recorded the response of $\mathrm{X}^{-/-} ; \mathrm{B} 1^{\Delta \mathrm{CaM}}$ OSNs to single brief $(100 \mathrm{~ms})$ pulses of the odorant and compared them with those of $\mathrm{X} 4^{-/-}, \mathrm{B} 1^{\Delta \mathrm{CaM}}$ and wild-type (WT) controls. We used two common odorants, heptaldehyde or amyl acetate, and discuss the data only for heptaldehyde, as the two odorants produced similar results. In line with previous findings (Song et al., 2008; Stephan et al., 2011), neither single mutant displayed significant changes in response amplitudes compared with WT mice (Fig. $1 A, B$; Table 1). Remarkably, $\mathrm{X} 4^{-/-} ; \mathrm{B} 1^{\Delta \mathrm{CaM}}$ double-mutant mice displayed significantly reduced response amplitudes compared with WT, $\mathrm{X} 4^{-1-}$, and $\mathrm{B} 1^{\Delta \mathrm{CaM}}$ mice across a wide range of odorant concentrations (Fig. $1 A, B$; Table 1 ), suggesting a reduction of resting sensitivity. In addition, the odorant concentration for halfmaximal EOG amplitude in $\mathrm{X}^{-1-} ; \mathrm{B} 1^{\Delta \mathrm{CaM}}$ mice is slightly higher than that of other genotypes. Specifically, the halfmaximal concentration is $2.0 \times 10^{-4} \mathrm{M}, 2.0 \times 10^{-4} \mathrm{M}, 2.4 \times$ $10^{-4} \mathrm{M}$, and $6.7 \times 10^{-4} \mathrm{M}$ for WT, $\mathrm{X} 4^{-l-}, \mathrm{B} 1^{\Delta \mathrm{CaM}}$ and $\mathrm{X} 4^{-\prime-}$; $\mathrm{B} 1^{\Delta \mathrm{CaM}}$ mice, respectively.

We then analyzed the onset and offset response kinetics. For onset kinetics, we measured the time to peak, defined as the time between the initiation of the odorant pulse and the peak of the response, and the rate of activation, defined as the change in EOG amplitude divided by the time from $1 \%$ to $99 \%$ of the peak response. Similar to previous findings (Song et al., 2008; Stephan et al., 2011), $\mathrm{X}^{-1-}$ and $\mathrm{B} 1^{\Delta \mathrm{CaM}}$ mice both displayed similar onset response kinetics compared with WT (Fig. 1C-E; Table 1). We found that $\mathrm{X} 4^{-1-} ; \mathrm{B} 1^{\Delta \mathrm{CaM}}$ mice also displayed no significant differences in the time to peak compared with $\mathrm{WT}, \mathrm{X} 4^{-1-}$, and $\mathrm{B} 1^{\Delta \mathrm{CaM}}$ mice, except at the highest concentration of heptaldehyde tested (Fig. 1C,D; Table 1). However, the rate of activation is significantly slower in $\mathrm{X}^{-/-} ; \mathrm{B} 1^{\Delta \mathrm{CaM}}$ mice (Fig. $1 C, E$; Table 1). For offset kinetics, conventionally, the response termination of WT mice fits well with a single exponential decay function (Song et al., 2008; Cygnar and Zhao, 2009; Stephan et al., 2011; Cygnar et al., 2012); however, we found that this method is not satisfactory to quantify the offset kinetics in the case of markedly slowed termination, such as those of $\mathrm{X} 4^{-1-} ; \mathrm{B} 1^{\Delta \mathrm{CaM}}$ mice or at higher odorant concentrations. For this reason, we calculated the area under the trace in the offset phase after normalization of each response to its peak amplitude (for specific integration time windows, see Materials and Methods). Using this method, larger area values indicate slower termination. Similar to previous findings (Song et al., 2008; Stephan et al., 2011), X4 $4^{-1-}$ and B1 ${ }^{\Delta \mathrm{CaM}}$ mice both displayed slowed response termination (Fig. 1F; Table 1). Interestingly, the termination deficits in $\mathrm{B}^{\Delta \mathrm{CaM}}$ were more obvious at concentrations $>10^{-3} \mathrm{M}$ heptaldehyde to the point where $\mathrm{B} 1^{\Delta \mathrm{CaM}}$ responses decayed nearly as slowly as those of
$\mathrm{X} 4^{-1-}$ mice (Fig. $1 F$ ). We found that response termination in $\mathrm{X} 4^{-1-} ; \mathrm{B} 1^{\Delta \mathrm{CaM}}$ mice closely matched that of $\mathrm{X} 4^{-1-}$ mice. Notably, the deficits seen in $\mathrm{X} 4^{-1-} ; \mathrm{B} 1^{\Delta \mathrm{CaM}}$ mice were never worse than in $\mathrm{X} 4^{-1-}$ mice, even at the highest odorant concentrations tested where both $\mathrm{X} 4^{-/-}$and $\mathrm{B} 1^{\Delta \mathrm{CaM}}$ mice displayed similar reductions in termination rate (Fig. $1 F$; Table 1 ).

The drastically impaired resting sensitivity of the doublemutant is quite striking. To control for possible changes in the abundance and localization of relevant proteins in $\mathrm{X} 4^{-1-}$; $\mathrm{B} 1^{\Delta \mathrm{CaM}}$ mice, we performed Western blotting and immunostaining on the olfactory epithelium for some known olfactory proteins. Western blotting showed that levels of two major transduction components, adenylyl cyclase 3 (AC3) and CNGA2, were not significantly changed in $\mathrm{X} 4^{-/-}, \mathrm{B} 1^{\Delta \mathrm{CaM}}$, or $\mathrm{X} 4^{-/-} ; \mathrm{B} 1^{\Delta \mathrm{CaM}}$ olfactory epithelium relative to WT (Fig. $2 A, B$ ). The level of OMP, a mature OSN marker, in $\mathrm{X} 4^{-/-} ; \mathrm{B} 1^{\Delta \mathrm{CaM}}$ mice was significantly reduced to $78.7 \pm 7.3 \%$ (mean $\pm \mathrm{SD}$ ) of the WT level, whereas the level of GAP43, an immature OSN marker, in $\mathrm{X} 4^{-1-} ; \mathrm{B} 1^{\Delta \mathrm{CaM}}$ mice was not significantly different (Fig. $2 A, B$ ). Immunostaining in $\mathrm{X} 4^{-1-} ; \mathrm{B} 1^{\Delta \mathrm{CaM}}$ epithelium showed that AC3 and CNGA2 were localized to the cilia layer similar to that of WT epithelium (Figs. 2, 3C). The staining pattern of OMP in $\mathrm{X}^{-1-}$; $\mathrm{B} 1^{\Delta \mathrm{CaM}}$ mice was indistinguishable from that of WT mice, and the percentage of OMP-positive cells within the olfactory epithelium was not significantly different between WT and in $\mathrm{X} 4^{-1-}$; $\mathrm{B} 1^{\Delta \mathrm{CaM}}$ mice at $56.9 \pm 5.3 \%$ and $60.2 \pm 6.6 \%($ mean $\pm \mathrm{SD})$, respectively (Fig. 2C).

Given the essential role of $\mathrm{Ca}^{2+}$ in mediating olfactory adaptation, we performed EOG recordings using a paired-pulse stimulation paradigm. In this paradigm, the olfactory epithelium was stimulated with two $100 \mathrm{~ms}$ odorant pulses separated by a $1 \mathrm{~s}$ interval (Song et al., 2008; Cygnar and Zhao, 2009; Stephan et al., 2011). Adaptation was represented as the amplitude of the second response relative to the amplitude of the first (for the net second response amplitude determination, see Materials and Methods). Consistent with previous findings (Song et al., 2008; Stephan et al., 2011), X4 $4^{-1-}$ mice overadapted relative to WT mice, whereas $\mathrm{B} 1^{\Delta \mathrm{CaM}}$ mice adapted similarly to WT (Fig. $3 A-C$; Table 1 ). We found that $\mathrm{X} 4^{-/-} ; \mathrm{B} 1^{\Delta \mathrm{CaM}}$ mice displayed markedly enhanced adaptation compared with WT and $\mathrm{B} 1^{\Delta \mathrm{CaM}}$ mice, similar to $\mathrm{X} 4^{-1-}$ mice (Fig. $3 A-C$; Table 1). However, $\mathrm{X} 4^{-1-} ; \mathrm{B} 1^{\Delta \mathrm{CaM}}$ mice did show a trend toward less adaptation compared with $\mathrm{X} 4^{-1-}$ mice. We also analyzed response latencies to the second stimulus, quantified as the time from presentation of the second pulse to the reversal point where the response changes from terminating to responding again. $\mathrm{X} 4^{-/-}$mice displayed significantly longer response latency to the second stimulus (Fig. 3D; Table 1), similar to the previous finding (Stephan et al., 2011). B1 ${ }^{\Delta \mathrm{CaM}}$ mice displayed similar second response latency to WT. Interestingly, $\mathrm{X} 4^{-1-} ; \mathrm{B} 1^{\Delta \mathrm{CaM}}$ mice displayed a second response latency longer than that of WT and $\mathrm{B} 1^{\Delta \mathrm{CaM}}$ mice, but shorter than that of X4 ${ }^{-/-}$ mice (Fig. 3D; Table 1). Even with these changes in response latencies, there were no significant differences in the time-topeak values for the second peaks (Fig. 3E; Table 1).

We next investigated whether $\mathrm{X} 4^{-{ }^{--}} ; \mathrm{B} 1^{\Delta \mathrm{CaM}}$ mice would display altered response decay during sustained stimulation as both $\mathrm{X} 4^{-1-}$ and $\mathrm{B} 1^{\Delta \mathrm{CaM}}$ mice displayed significantly less decay in our previous studies. To do this, we stimulated the olfactory epithelium with a $10 \mathrm{~s}$ pulse of odorant (Fig. $4 A$ ). Similar to the responses to brief odorant pulses $\mathrm{X} 4^{-/-} ; \mathrm{B} 1^{\Delta \mathrm{CaM}}$ mice displayed smaller response amplitudes in response to a sustained stimulus compared with all other genotypes (Fig. 4B; Table 1). X4 $4^{-1-}$; $\mathrm{B} 1^{\Delta \mathrm{CaM}}$ mice as well as $\mathrm{B} 1^{\Delta \mathrm{CaM}}$ displayed significantly prolonged 
A $10^{-3} \mathrm{M}$ heptaldehyde

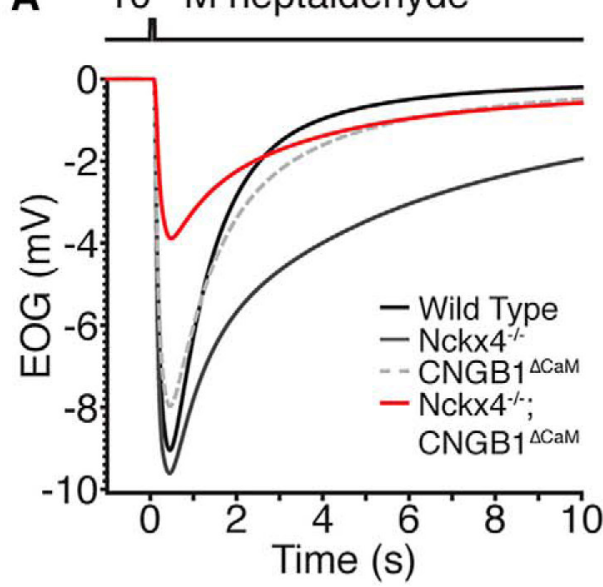

C

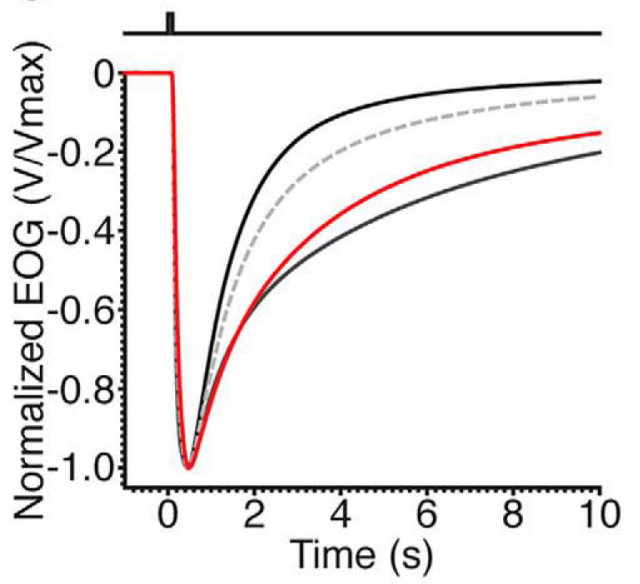

E

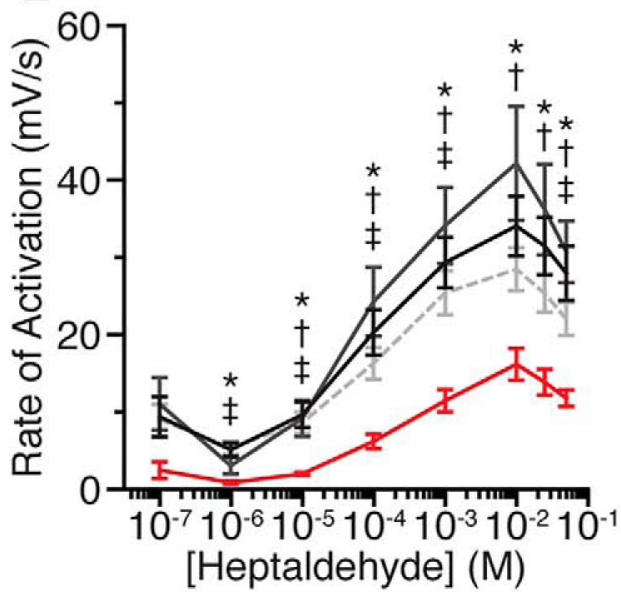

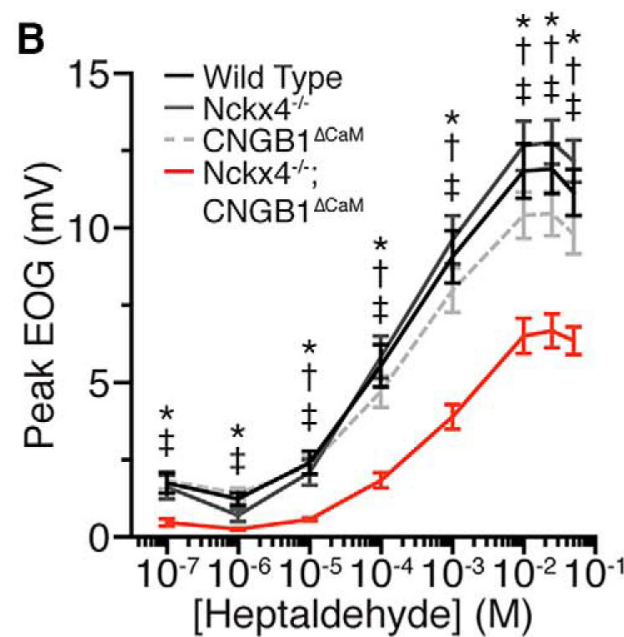

D
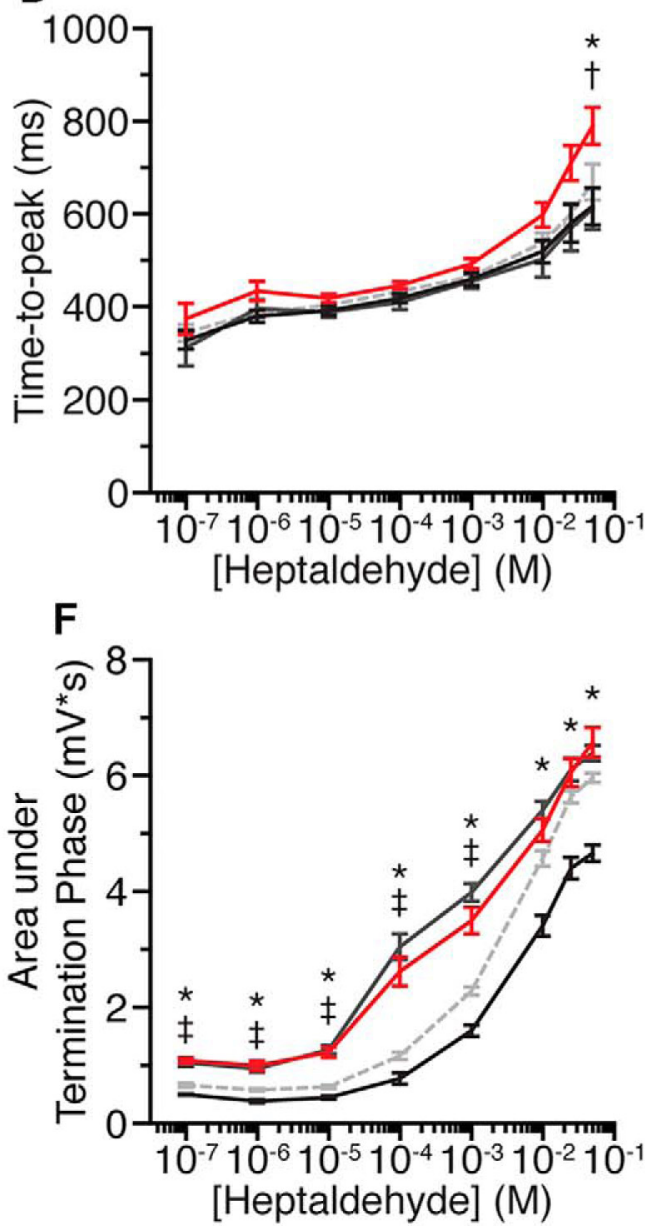

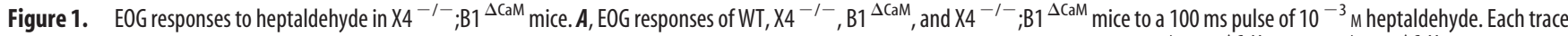
represents an average of a single recording from multiple mice. Trace color codes also apply to $B-F$. $B$, Dose-response relationships of WT, X4 ${ }^{-1-}, B 1^{\Delta C a M}$, and X4 ${ }^{-\prime-} ; B 1^{\Delta C a M}$ mice EOG peaks evoked by single, 100 ms pulses of heptaldehyde. $C$, EOG responses from $A$, normalized relative to their peaks to allow for comparison of activation and termination kinetics. $D$, Time to peak, defined as the time from the initiation of the odorant pulse to the response peak. $\boldsymbol{E}$, Activation rate, defined as the change in EOG amplitude divided by the time between $1 \%$ and $99 \%$ of the peak amplitude. $\boldsymbol{F}$, Response termination, quantified as the area under the trace, after normalization of each response to its peak amplitude, in the termination phase of the response (see Materials and Methods). Error bars indicate SEM. Statistical significance was determined by one-way ANOVA followed by a Tukey's HSD post hoc test. ${ }^{*} p<0.05$, WT versus X4 ${ }^{-1-} ;$ B $1 ~^{\Delta \text { CaM }}$. $^{\dagger} p<0.05, \mathrm{X}^{-1-}$ versus

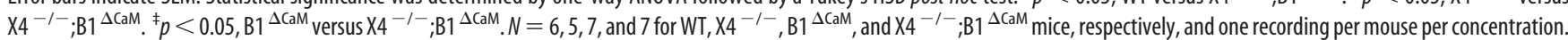

response onset, quantified as time to peak, in response to the sustained stimulation compared with WT mice (Fig. 4C; Table 1). $\mathrm{X} 4^{-1-}$ mice also trended toward a prolonged response onset compared with WT mice. Quantification of response decay was performed by calculating the area under the trace, after normalization of each response to the peak amplitude, from the peak time to the time point $9 \mathrm{~s}$ beyond the peak. In agreement with previous studies, $\mathrm{X} 4^{-1-}$ and $\mathrm{B} 1^{\Delta \mathrm{CaM}}$ mice both displayed less 
Table 1. EOG responses to heptaldehyde in $\mathrm{X4}{ }^{-/-} ; \mathrm{B} 1^{\Delta \mathrm{CaM}}$ mice ${ }^{a}$

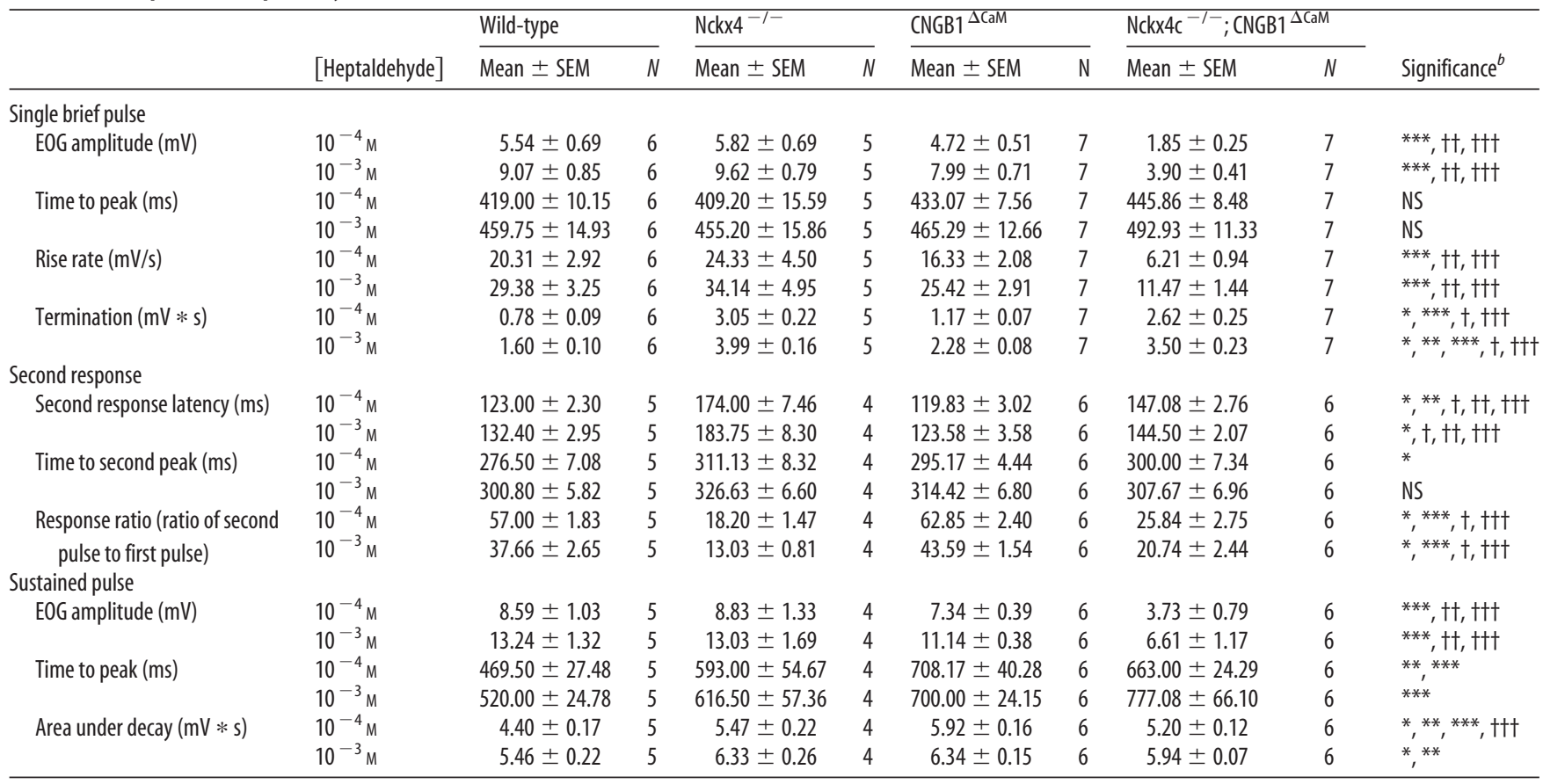

${ }^{a}$ Error is represented as SEM. The number of mice is indicated, with one recording per mouse per concentration.

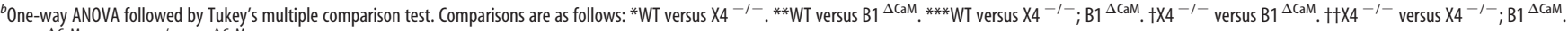
$+++B 1^{\Delta \mathrm{CaM}}$ versus $\mathrm{X} 4^{-1-} ; \mathrm{B} 1^{\Delta \mathrm{CaM}}$.

response decay during sustained stimulation compared with WT. $\mathrm{X} 4^{-/-} ; \mathrm{B} 1^{\Delta \mathrm{CaM}}$ mice also showed less response decay compared with WT, but the response decay did not differ significantly from $\mathrm{X} 4^{-/-}$or $\mathrm{B} 1^{\Delta \mathrm{CaM}}$ mice (Fig. $4 A, D$; Table 1 ).

\section{Discussion}

In this study, we show that olfactory sensory neurons lacking both the extrusion of $\mathrm{Ca}^{2+}$ by NCKX 4 and $\mathrm{Ca}^{2+} / \mathrm{CaM}$-mediated CNG channel desensitization display reduced response amplitudes to odorant stimulation, suggesting that the interaction of these two regulatory mechanisms contributes to setting olfactory sensitivity at rest. This is particularly interesting in light of the fact that neither of the single mutant mice $\left(\mathrm{X}^{-l-}\right.$ or $\left.\mathrm{B} 1^{\Delta \mathrm{CaM}}\right)$ displays reduced resting sensitivity.

Sensory receptor cells maintain high sensitivity at rest to allow for a robust response to weak stimuli that are often at or near the physical limit (Baylor et al., 1979; Crawford and Fettiplace, 1985; Menini et al., 1995; Bhandawat et al., 2005; Bhandawat et al., 2010). This high resting sensitivity also allows sensory receptor cells to respond to a broad range of stimulus strengths through adaptation (Torre et al., 1995), providing an organism the means to accommodate complex and dynamic stimulus environments. While the mechanisms responsible for setting the resting sensitivity of sensory receptor cells are not well understood, it has generally been assumed that the sensitivity is set primarily by how effectively the components in the activation cascade of transduction can be stimulated. The findings presented here, in conjunction with our previous work (Cygnar and Zhao, 2009), suggest that mechanisms that are conventionally considered negative regulatory mechanisms are also critical for proper olfactory sensitivity.

How could the simultaneous loss of these two regulatory mechanisms reduce the resting sensitivity of OSNs? It is known that many OSNs possess spontaneous activity (Duchamp-Viret et al., 2000; Delay and Restrepo, 2004; Re- isert, 2010; Connelly et al., 2013). This spontaneous activity is thought to stem primarily from the spontaneous activation of ORs in the absence of ligand binding (Reisert, 2010; Connelly et al., 2013). Spontaneously activated ORs trigger generation of cAMP, opening of the CNG channel, and influx of $\mathrm{Ca}^{2+}$ (Reisert, 2010). In WT OSNs, multiple mechanisms work together to ensure low resting $\mathrm{Ca}^{2+}$ levels in the cilia, thereby limiting negative feedback to the transduction cascade and allowing OSNs to maintain high resting response sensitivity. $\mathrm{Ca}^{2+}$ generated by spontaneous activity can be controlled through desensitization of the CNG channel, limiting $\mathrm{Ca}^{2+}$ influx, and through activity of NCKX4, facilitating $\mathrm{Ca}^{2+} \mathrm{ex}^{-}$ trusion. A potential elevation of $\mathrm{Ca}^{2+}$ in $\mathrm{B} 1^{\Delta \mathrm{CaM}}$ OSNs due to a lack of CNG desensitization and increased $\mathrm{Ca}^{2+}$ influx, however, could be managed through $\mathrm{Ca}^{2+}$ extrusion by NCKX4, and a potential excess of cilial $\mathrm{Ca}^{2+}$ due to lack of $\mathrm{Ca}^{2+}$ extrusion in $\mathrm{X} 4^{-1-}$ OSNs could be maintained at low levels through restriction of influx by desensitization of the CNG channel coupled with $\mathrm{Ca}^{2+}$ buffering and diffusion. These scenarios are consistent with the observation that neither $\mathrm{X} 4^{-1-}$ nor $\mathrm{B} 1^{\Delta \mathrm{CaM}}$ OSNs show loss of resting sensitivity. In both of these scenarios, degradation of cAMP by $\mathrm{Ca}^{2+}$-activated PDE1C also likely plays a role by promoting closure of the CNG channel and limiting influx of $\mathrm{Ca}^{2+}$. When both the extrusion of $\mathrm{Ca}^{2+}$ by NCKX4 and the limitation of $\mathrm{Ca}^{2+}$ influx by the $\mathrm{CNG}$ channel desensitization are lacking, spontaneous activity will lead to increased levels of $\mathrm{Ca}^{2+}$ in the cilia, which will feed back onto the transduction components and leave the system in a chronic negatively regulated state, resulting in a loss of resting sensitivity. Elevated levels of $\mathrm{Ca}^{2+}$ in the cilia could enhance the catalytic activity of PDE1C (Yan et al., 1995), leading to increased cAMP degradation, and also inhibit AC3 activity by stimulating CaMKII-mediated phosphorylation (Wei et al., 1998; Leinders-Zufall et al., 1999), leading to de- 


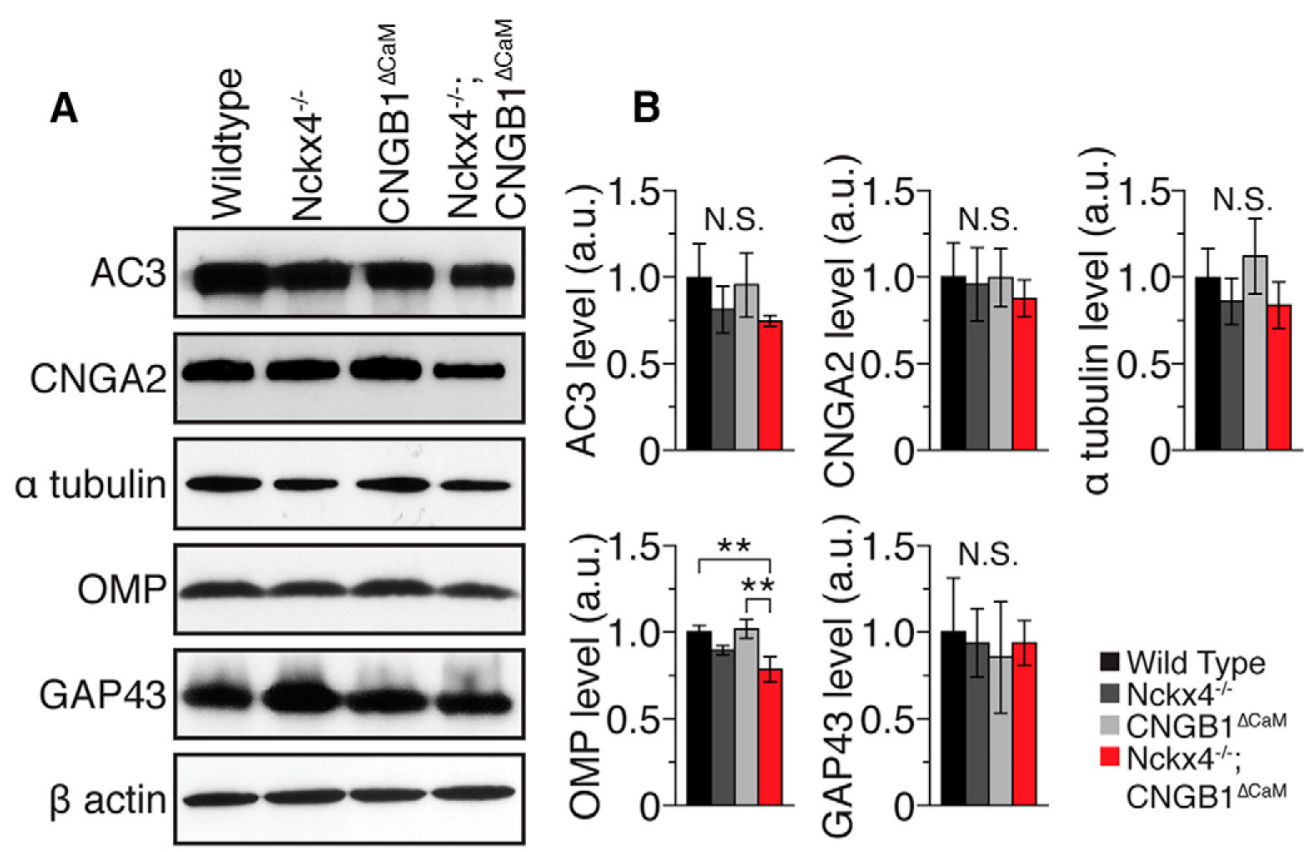

C
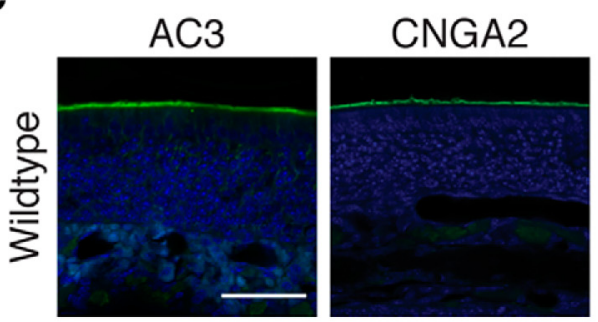

Acetylated
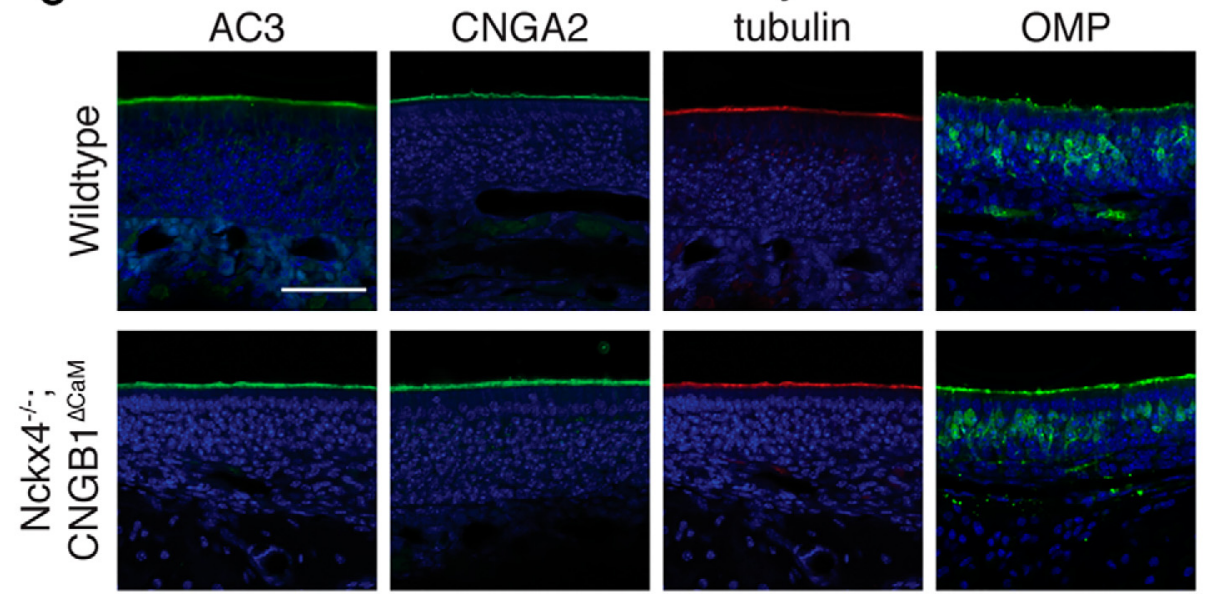

Figure 2. Molecular characterization of $\mathrm{X}^{-I-} ; \mathrm{B} 1^{\Delta \mathrm{CaM}}$ olfactory epithelium. $\boldsymbol{A}$, Western blot analysis of protein abundance in the olfactory epithelium. Example Western blots are shown for AC3, CNGA2, $\alpha$ tubulin, OMP, GAP43, and $\beta$ actin. $B$, Quantification of Western blotting shown in $A$. Values are normalized to $\beta$ actin and shown relative to WT in arbitrary units. Data are the average of three independent sets of mice, with each set consisting of one mouse from each genotype. Western blotting was performed on each set $2-4$ times to control for technical error. Error bars indicate SD. ${ }^{* *} p<0.01$ (one-way ANOVA followed by a Tukey's HSD post hoc test). C, Immunostaining of olfactory epithelium sections from WT and X4 ${ }^{-/-} ; B 1^{\Delta \mathrm{CaM}}$ mice. Sections were counterstained with DAPI (blue) to label cell nuclei. Scale bar, $50 \mu \mathrm{m}$.

creased cAMP synthesis. Sustained elevation of $\mathrm{Ca}^{2+}$ levels could also inhibit ANO2 (Reisert et al., 2003, 2005; Pifferi et al., 2009; Vocke et al., 2013) and contribute to the reduced response amplitudes observed in $\mathrm{X} 4^{-/-} ; \mathrm{B} 1^{\Delta \mathrm{CaM}}$ mice. In line with these predictions, the reduction in response amplitude of $\mathrm{X} 4^{-1-} ; \mathrm{B} 1^{\Delta \mathrm{CaM}}$ OSNs should not occur in OSNs that are not spontaneously active. This prediction can be tested at the single-cell level in future studies.

$\mathrm{X} 4^{-/-} ; \mathrm{B} 1^{\Delta \mathrm{CaM}}$ mice exhibited an interesting phenotype with respect to the response termination kinetics. Although $\mathrm{X} 4^{-1-}$ and $\mathrm{B} 1^{\Delta \mathrm{CaM}}$ mice both displayed slowed response termination kinetics (Song et al., 2008; Stephan et al., 2011), there were no additive effects in response termination kinetics in $\mathrm{X} 4^{-/-} ; \mathrm{B} 1^{\Delta \mathrm{CaM}}$ mice. $\mathrm{X} 4^{-/-} ; \mathrm{B} 1^{\Delta \mathrm{CaM}}$ mice exhibited prolonged response termination most similar to $\mathrm{X} 4^{-/-}$mice (Fig. $1)$. In $\mathrm{X} 4^{-/-} ; \mathrm{B} 1^{\Delta \mathrm{CaM}}$ OSNs, despite the lack of CNG channel desensitization, the excess of cilial $\mathrm{Ca}^{2+}$ could trigger accelerated degradation of cAMP by PDE1C, which in turn could promote closure of the $\mathrm{CNG}$ channel and limit further influx of $\mathrm{Ca}^{2+}$. The total amount of $\mathrm{Ca}^{2+}$ influx in $\mathrm{X}^{-/-} ; \mathrm{B} 1^{\Delta \mathrm{CaM}}$ OSNs is likely be smaller than that in $\mathrm{B1}^{\Delta \mathrm{CaM}}$ OSNs. This phenotype is consistent with the thought that the response termination is predominantly governed by extrusion of $\mathrm{Ca}^{2+}$ by NCKX4 (Stephan et al., 2011).

$\mathrm{X} 4^{-/-} ; \mathrm{B} 1^{\Delta \mathrm{CaM}}$ mice did exhibit a small but significant reduction in OMP levels by Western blotting (Fig. 2). However, we did not observe a change in the relative proportion of OMP-positive cells in $\mathrm{X} 4^{-1-} ; \mathrm{B} 1^{\Delta \mathrm{CaM}}$ mice compared with WT mice. Additionally, the level of GAP43 protein in $\mathrm{X}^{-/-} ; \mathrm{B} 1^{\Delta \mathrm{CaM}}$ mice was not significantly different from that of WT mice (Fig. 2). These results suggest that the reduced OMP level in $\mathrm{X} 4^{-1-} ; \mathrm{B} 1^{\Delta \mathrm{CaM}}$ mice reflects a reduction in the amount of OMP expressed by mature 

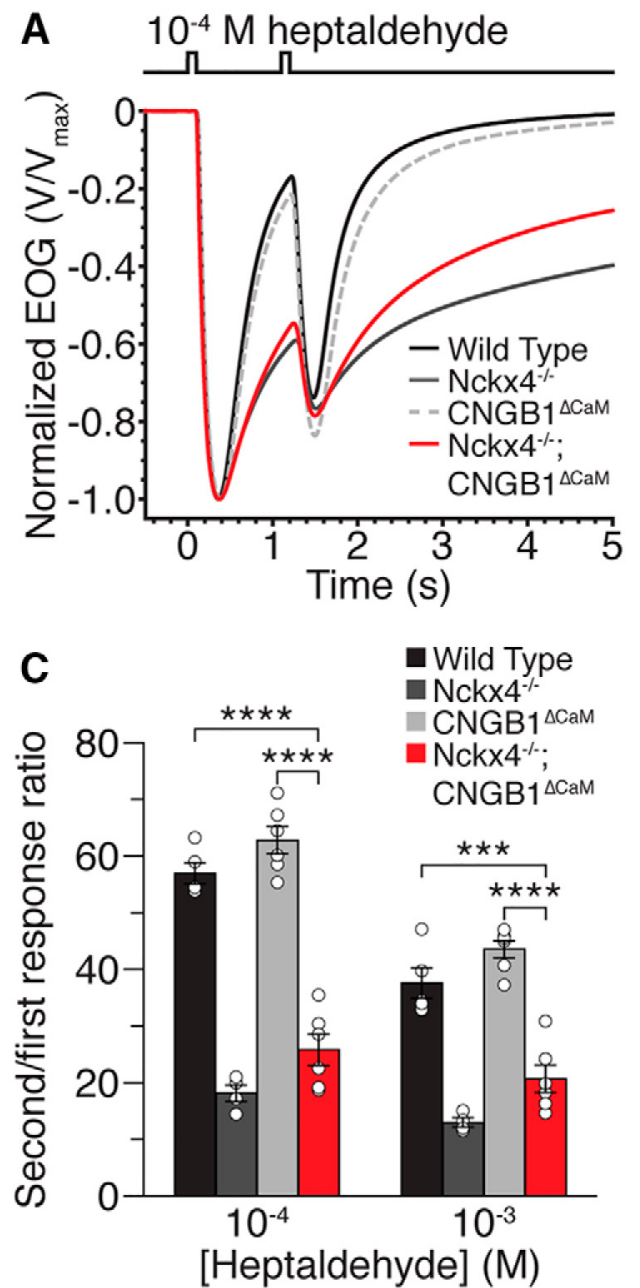

B

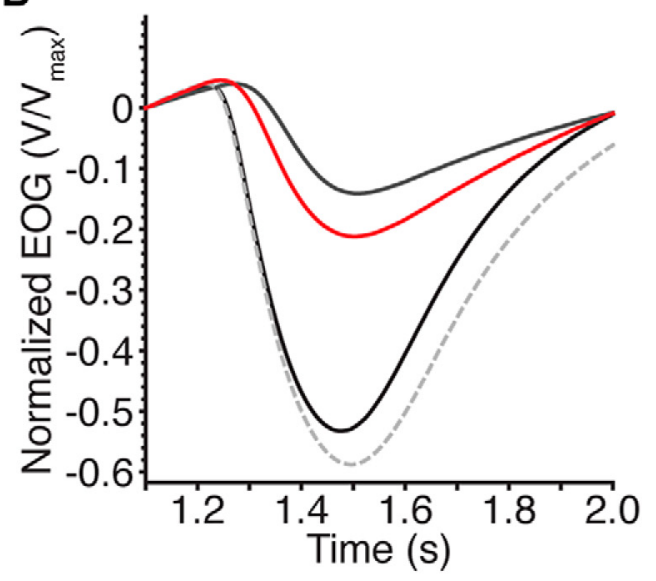

D

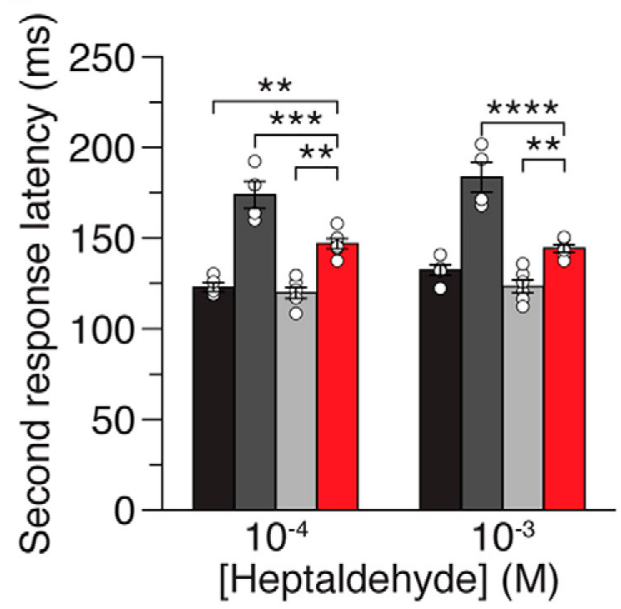

E

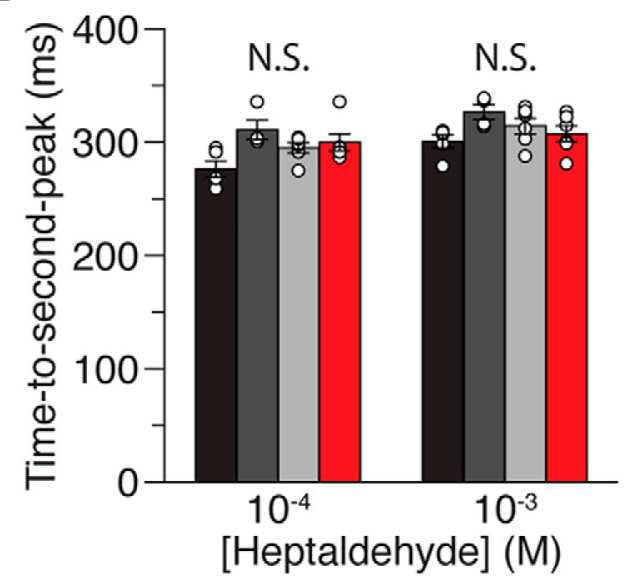

Figure 3. Paired-pulse adaptation analysis of X4 ${ }^{-I-} ; \mathrm{B} 1^{\Delta \mathrm{CaM}}$ mice. $A$, Averaged and normalized EOG responses to two $100 \mathrm{~ms}$ pulses of $10^{-4} \mathrm{M}$ heptaldehyde separated by a 1 sinterpulse interval. Trace color codes also apply to $\boldsymbol{B}$. $\boldsymbol{B}$, Responses from $\boldsymbol{A}$, plotted on an expanded time axis and aligned at the initiation of the second pulse for comparison of kinetics and net second response amplitudes. $\boldsymbol{C}$, Amplitude ratios of the second (adapted) EOG response relative to the first (for details on calculation of the net second response amplitude, see Materials and Methods). $\boldsymbol{D}$, Response latency for the second pulse, calculated as the time from presentation of the second odor pulse to the reversal point where the response changes from terminating to responding. $\boldsymbol{E}$, Time to peak for the second response, defined as the time from initiation of the second odor pulse to the peak of the second response. Open circles represent individual values for each genotype. Error bars indicate SEM. ${ }^{* *} p<0.01$ (one-way ANOVA followed by a Tukey's HSD post hoc test). ${ }^{* * *} p<0.001$ (one-way ANOVA followed by a Tukey's HSD posthoc test). ${ }^{* * *} p<0.0001$ (one-way ANOVA followed by a Tukey's HSD post hoc test). N =6, 5, 7, and 7 for WT, X4 ${ }^{-/-}$, B1 ${ }^{\Delta \text { CaM }}$, and $\mathrm{X} 4^{-/-} ; \mathrm{B} 1^{\Delta \mathrm{CaM}}$ mice, respectively, and one recording per mouse per concentration.

OSNs rather than a reduction in the proportion of mature OSNs. Previously, OMP null OSNs were shown to display reduced response amplitudes and slowed response kinetics (Buiakova et al., 1996; Ivic et al., 2000; Reisert et al., 2007; Lee et al., 2011; Dibat- tista and Reisert, 2016). However, given the lack of observable EOG defects in mice heterozygous for the OMP gene (Ivic et al., 2000 ), in which the OMP level is $40 \%-50 \%$ of the WT (Buiakova et al., 1996), the reduced sensitivity phenotype in $\mathrm{X} 4^{-/-} ; \mathrm{B} 1^{\Delta \mathrm{CaM}}$ 

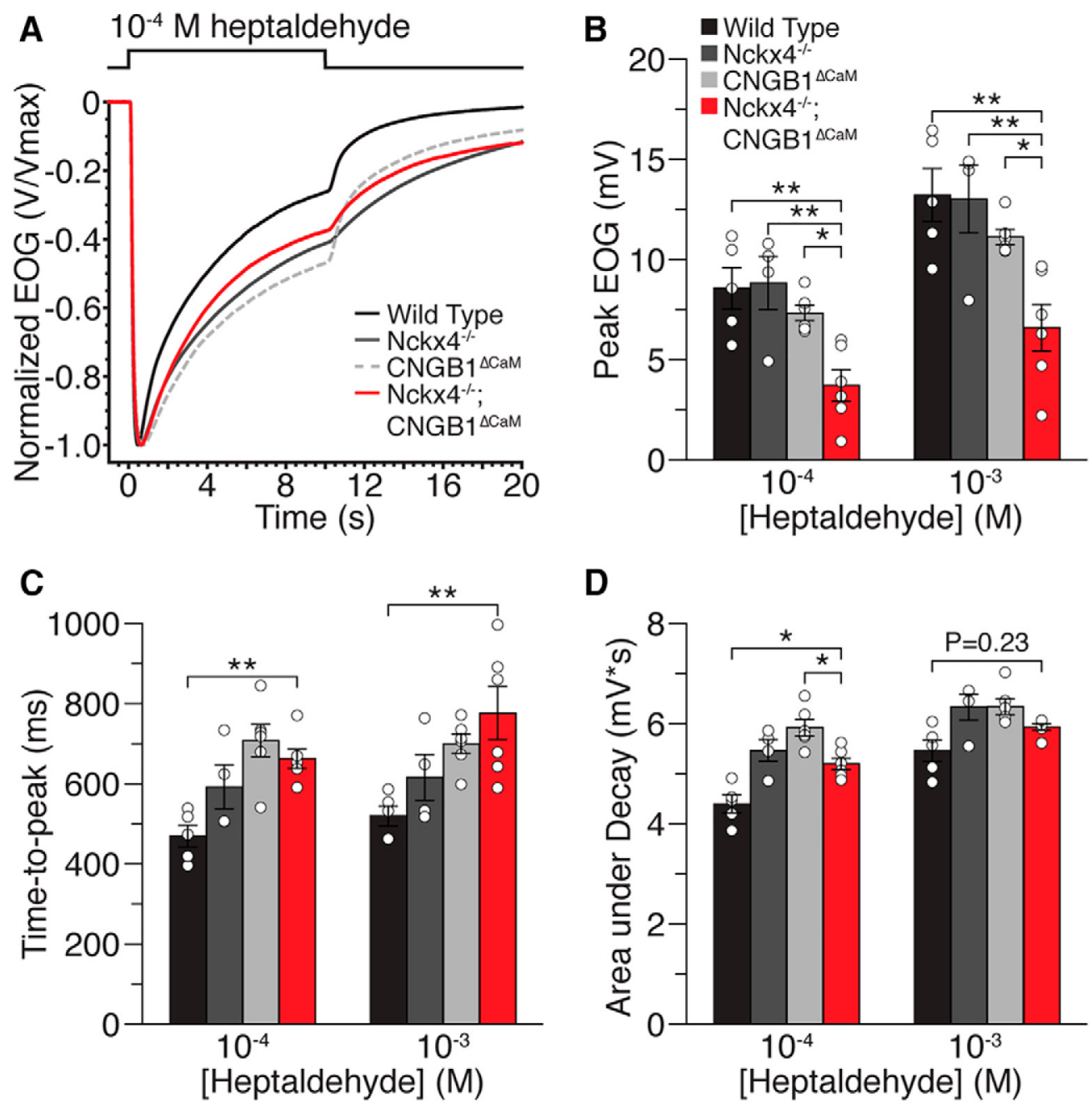

Figure 4. EOG responses to a sustained heptaldehyde pulse. The olfactory epithelium was stimulated with a single 10 s pulse of heptaldehyde. $\boldsymbol{A}$, Traces of averaged and normalized E0 $\mathrm{G}$ responses of WT, $\mathrm{X}^{-I-}, \mathrm{B} 1^{\Delta \mathrm{CaM}}$, and X4 ${ }^{-I-} ; \mathrm{B} 1^{\Delta \mathrm{CaM}}$ mice to $10^{-4} \mathrm{M}$ heptaldehyde. $B$, Peak response amplitudes to $10^{-4} \mathrm{M}$ and $10^{-3} \mathrm{M}$ heptaldehyde, respectively. $C$, Time to peak, defined as the time from the initiation of the odorant pulse to the response peak. $D$, Response decay, quantified as the area under the trace, after normalization of each response to the peak amplitude, from the peak time to the time point 9 s beyond the peak. Open circles represent individual values for each genotype. Error bars indicate SEM. ${ }^{*} p<0.05$ (one-way ANOVA followed by a Tukey's HSD post hoc test). ${ }^{* *} p<0.01$ (one-way ANOVA followed by a Tukey's HSD post hoc test). $N=6,5,7$, and 7 for WT, $\mathrm{X} 4^{-1-}, \mathrm{B} 1^{\Delta \mathrm{CaM}}$, and X4 ${ }^{-1-} ; \mathrm{B} 1^{\Delta \mathrm{CaM}}$ mice, respectively.

mice is unlikely to be caused by the decreased levels of OMP. The cause and physiological significance of the reduced OMP level in $\mathrm{X} 4^{-1-} ; \mathrm{B} 1^{\Delta \mathrm{CaM}}$ mice remain to be further studied. It should also be noted that, although we did not see significant changes in the levels of either AC3 or CNGA2 by Western blotting, we cannot rule out the possibility that levels of other transduction components may be altered in $\mathrm{X} 4^{-/-} ; \mathrm{B} 1^{\Delta \mathrm{CaM}}$ mice that could contribute to the observed decrease in response amplitude.

This study has also allowed us to directly compare $\mathrm{X} 4^{-1-}$ mice to $\mathrm{B} 1^{\Delta \mathrm{CaM}}$ mice, more specifically, in their response termination kinetics and response decay during a sustained stimulus. For response termination, both $\mathrm{X} 4^{-/-}$and $\mathrm{B} 1^{\Delta \mathrm{CaM}}$ mice displayed significantly slower termination than WT mice, but termination in $\mathrm{X} 4^{-1-}$ mice was almost always slower than termination in B1 ${ }^{\Delta \mathrm{CaM}}$ mice (Fig. $1 F$ ). As the odorant concentration increased, however, the impact of CNG channel desensitization increased to the point where $\mathrm{X} 4^{-1-}$ and $\mathrm{B} 1^{\Delta \mathrm{CaM}}$ terminated at nearly the same rate (Fig. $1 F$ ). This concentration-dependent phenotype emphasizes the critical role of $\mathrm{Ca}^{2+} / \mathrm{CaM}$-mediated $\mathrm{CNG}$ channel desensitization in the control of $\mathrm{Ca}^{2+}$ influx. For response decay during a sustained pulse, at the two concentrations tested,
$\mathrm{X} 4^{-1-}$ and $\mathrm{B} 1^{\Delta \mathrm{CaM}}$ mice showed nearly identical phenotypes of less response decay (Fig. 4D). It is interesting that lacking either of two distinct mechanisms, controlling $\mathrm{Ca}^{2+}$ influx or extrusion, results in the same response phenotype in the presence of sustained odor stimulation.

Analysis of $\mathrm{X}^{-1-} ; \mathrm{B} 1^{\Delta \mathrm{CaM}}$ mice has also garnered us further insight into the role of the CNG channel desensitization in paired-pulse adaptation. Although we did not see significant alterations in $\mathrm{B} 1^{\Delta \mathrm{CaM}}$ mice compared with WT mice with regard to the second response size and second response latency, similar to previous reports (Song et al., 2008), we did notice influences of the CNG channel desensitization in the background of Nckx $4^{-1-}$. Specifically, the prolonged latency to the second stimulation observed in $\mathrm{X} 4^{-1-}$ mice was partially but significantly rescued in $\mathrm{X} 4^{-1-} ; \mathrm{B} 1^{\Delta \mathrm{CaM}}$ mice (Fig. $3 D$ ). There was also a partial rescue in $\mathrm{X} 4^{-/-} ; \mathrm{B} 1^{\Delta \mathrm{CaM}}$ mice of the reduced ratio of the second response amplitude relative to the first seen in $\mathrm{X} 4^{-1-}$ mice (Fig. $3 C)$. Thus, as an integral mechanism for olfactory adaptation, $\mathrm{Ca}^{2+} / \mathrm{CaM}$-mediated CNG channel desensitization contributes to the overadaptation phenotype of $\mathrm{X}^{-1-}$ mice in the pairedpulse adaptation paradigm. In the presence of an effective $\mathrm{Ca}^{2+}$ 
removal provided by NCKX4, its role, when lacking, can be compensated for by other mechanisms.

How could the altered EOG response in $\mathrm{X}^{-1-} ; \mathrm{B} 1^{\Delta \mathrm{CaM}}$ mice relate to action potential (AP) firing of individual OSNs? As the EOG represents an ensemble of responses from individual OSNs, individual OSNs in $\mathrm{X}^{-l-} ; \mathrm{B} 1^{\Delta \mathrm{CaM}}$ mice could display reduced response amplitudes, enhanced adaptation, and slowed termination kinetics. Previously, it has been demonstrated that AP firing occurs predominantly during the rising phase of the transduction current in individual OSNs (Reisert and Matthews, 1999; Reisert and Matthews, 2001) and can be observed in OSNs, such as OSNs lacking $\mathrm{ANO} 2$, that have substantially reduced response amplitudes (Pietra et al., 2016). The lack of AP firing during the falling phase is thought to be due to a progressive inactivation of voltagegated sodium channels (Trotier and MacLeod, 1983; Trotier, 1994; Reisert and Matthews, 1999; Reisert and Matthews, 2001). Thus, despite their substantially reduced EOG amplitude, OSNs in $\mathrm{X}^{-I-} ; \mathrm{B} 1^{\Delta \mathrm{CaM}}$ mice should be capable of firing APs in response to odorant stimulation at rest. However, the slowed termination kinetics and enhanced adaptation would prevent prolonged AP firing and reduce AP firing to repeated stimulation in $\mathrm{X}^{-1-} ; \mathrm{B} 1^{\Delta \mathrm{CaM}}$ ONSs, similar to that seen in $\mathrm{X}^{-1-}$ OSNs (Stephan et al., 2011). Single-cell recording studies would be required to know for certain.

Together, our study of $\mathrm{X}^{-/-} ; \mathrm{B} 1^{\Delta \mathrm{CaM}}$ double-mutant mice has allowed us to observe how two mechanisms conventionally considered negative regulatory mechanisms interact to regulate the olfactory response. In particular, this study has revealed a fundamental role for $\mathrm{Ca}^{2+}$ regulation in setting olfactory sensitivity. Going forward, it will ultimately be interesting to determine how all of the regulatory mechanisms interact to promote high sensitivity and robust control of olfactory adaptation. In addition, this work may prove insightful for the study of resting sensitivity in other sensory receptor cells.

\section{References}

Baylor DA, Lamb TD, Yau KW (1979) The membrane current of single rod outer segments. J Physiol 288:589-611. CrossRef Medline

Bhandawat V, Reisert J, Yau KW (2005) Elementary response of olfactory receptor neurons to odorants. Science 308:1931-1934. CrossRef Medline

Bhandawat V, Reisert J, Yau KW (2010) Signaling by olfactory receptor neurons near threshold. Proc Natl Acad Sci U S A 107:18682-18687. CrossRef Medline

Boekhoff I, Breer H (1992) Termination of second messenger signaling in olfaction. Proc Natl Acad Sci U S A 89:471-474. CrossRef Medline

Bradley J, Reuter D, Frings S (2001) Facilitation of calmodulin-mediated odor adaptation by cAMP-gated channel subunits. Science 294:21762178. CrossRef Medline

Bradley J, Bönigk W, Yau KW, Frings S (2004) Calmodulin permanently associates with rat olfactory $\mathrm{CNG}$ channels under native conditions. Nat Neurosci 7:705-710. CrossRef Medline

Buiakova OI, Baker H, Scott JW, Farbman A, Kream R, Grillo M, Franzen L, Richman M, Davis LM, Abbondanzo S, Stewart CL, Margolis FL (1996) Olfactory marker protein (OMP) gene deletion causes altered physiological activity of olfactory sensory neurons. Proc Natl Acad Sci U S A 93: 9858-9863. CrossRef Medline

Connelly T, Savigner A, Ma M (2013) Spontaneous and sensory-evoked activity in mouse olfactory sensory neurons with defined odorant receptors. J Neurophysiol 110:55-62. CrossRef Medline

Crawford AC, Fettiplace R (1985) The mechanical properties of ciliary bundles of turtle cochlear hair cells. J Physiol 364:359-379. CrossRef Medline

Cygnar KD, Zhao H (2009) Phosphodiesterase 1C is dispensable for rapid response termination of olfactory sensory neurons. Nat Neurosci 12:454462. CrossRef Medline

Cygnar KD, Stephan AB, Zhao H (2010) Analyzing responses of mouse olfactory sensory neurons using the air-phase electroolfactogram recording. J Vis Exp 37:pii1850. CrossRef Medline
Cygnar KD, Collins SE, Ferguson CH, Bodkin-Clarke C, Zhao H (2012) Phosphorylation of adenylyl cyclase III at serine1076 does not attenuate olfactory response in mice. J Neurosci 32:14557-14562. CrossRef Medline

Delay R, Restrepo D (2004) Odorant responses of dual polarity are mediated by cAMP in mouse olfactory sensory neurons. J Neurophysiol 92: 1312-1319. CrossRef Medline

Dibattista M, Reisert J (2016) The odorant receptor-dependent role of olfactory marker protein in olfactory receptor neurons. J Neurosci 36:29953006. CrossRef Medline

Duchamp-Viret P, Duchamp A, Chaput MA (2000) Peripheral odor coding in the rat and frog: quality and intensity specification. J Neurosci 20:23832390. Medline

Ferguson CH, Zhao H (2016) Cyclic AMP signaling in the main olfactory epithelium. In: Chemosensory transduction (Zufall F, Munger SD, eds), pp 123-140: New York: Elsevier.

Firestein S (2001) How the olfactory system makes sense of scents. Nature 413:211-218. CrossRef Medline

Firestein S, Darrow B, Shepherd GM (1991) Activation of the sensory current in salamander olfactory receptor neurons depends on a $G$ proteinmediated cAMP second messenger system. Neuron 6:825-835. CrossRef Medline

Ivic L, Pyrski MM, Margolis JW, Richards LJ, Firestein S, Margolis FL (2000) Adenoviral vector-mediated rescue of the OMP-null phenotype in vivo. Nat Neurosci 3:1113-1120. CrossRef Medline

Kaupp UB (2010) Olfactory signalling in vertebrates and insects: differences and commonalities. Nat Rev Neurosci 11:188-200. CrossRef Medline

Kleene SJ (2008) The electrochemical basis of odor transduction in vertebrate olfactory cilia. Chem Senses 33:839-859. CrossRef Medline

Lee AC, He J, Ma M (2011) Olfactory marker protein is critical for functional maturation of olfactory sensory neurons and development of mother preference. J Neurosci 31:2974-2982. CrossRef Medline

Leinders-Zufall T, Ma M, Zufall F (1999) Impaired odor adaptation in olfactory receptor neurons after inhibition of $\mathrm{Ca}^{2+} /$ calmodulin kinase II. J Neurosci 19:RC19. Medline

Liu M, Chen TY, Ahamed B, Li J, Yau KW (1994) Calcium-calmodulin modulation of the olfactory cyclic nucleotide-gated cation channel. Science 266:1348-1354. CrossRef Medline

Matthews HR, Reisert J (2003) Calcium, the two-faced messenger of olfactory transduction and adaptation. Curr Opin Neurobiol 13:469-475. CrossRef Medline

Menini A, Picco C, Firestein S (1995) Quantal-like current fluctuations induced by odorants in olfactory receptor cells. Nature 373:435-437. CrossRef Medline

Munger SD, Lane AP, Zhong H, Leinders-Zufall T, Yau KW, Zufall F, Reed RR (2001) Central role of the CNGA4 channel subunit in $\mathrm{Ca}^{2+}$ calmodulin-dependent odor adaptation. Science 294:2172-2175. CrossRef Medline

Pietra G, Dibattista M, Menini A, Reisert J, Boccaccio A (2016) The $\mathrm{Ca}^{2+}$ activated $\mathrm{Cl}^{-}$channel TMEM16B regulates action potential firing and axonal targeting in olfactory sensory neurons. J Gen Physiol 148:293-311. CrossRef Medline

Pifferi S, Dibattista M, Menini A (2009) TMEM16B induces chloride currents activated by calcium in mammalian cells. Pflugers Arch 458:10231038. CrossRef Medline

Reisert J (2010) Origin of basal activity in mammalian olfactory receptor neurons. J Gen Physiol 136:529-540. CrossRef Medline

Reisert J, Matthews HR (1998) $\mathrm{Na}+$-dependent $\mathrm{Ca}^{2+}$ extrusion governs response recovery in frog olfactory receptor cells. J Gen Physiol 112:529 535. CrossRef Medline

Reisert J, Matthews HR (1999) Adaptation of the odour-induced response in frog olfactory receptor cells. J Physiol 519:801-813. CrossRef Medline

Reisert J, Matthews HR (2001) Response properties of isolated mouse olfactory receptor cells. J Physiol 530:113-122. CrossRef Medline

Reisert J, Bauer PJ, Yau KW, Frings S (2003) The Ca-activated Cl channel and its control in rat olfactory receptor neurons. J Gen Physiol 122:349363. CrossRef Medline

Reisert J, Lai J, Yau KW, Bradley J (2005) Mechanism of the excitatory Clresponse in mouse olfactory receptor neurons. Neuron 45:553-561. CrossRef Medline

Reisert J, Yau KW, Margolis FL (2007) Olfactory marker protein modu- 
lates the cAMP kinetics of the odour-induced response in cilia of mouse olfactory receptor neurons. J Physiol 585:731-740. CrossRef Medline

Scott JW, Scott-Johnson PE (2002) The electroolfactogram: a review of its history and uses. Microsc Res Tech 58:152-160. CrossRef Medline

Song Y, Cygnar KD, Sagdullaev B, Valley M, Hirsh S, Stephan A, Reisert J, Zhao H (2008) Olfactory CNG channel desensitization by $\mathrm{Ca}^{2+} / \mathrm{CaM}$ via the $\mathrm{B} 1 \mathrm{~b}$ subunit affects response termination but not sensitivity to recurring stimulation. Neuron 58:374-386. CrossRef Medline

Stephan AB, Tobochnik S, Dibattista M, Wall CM, Reisert J, Zhao H (2011) The $\mathrm{Na}(+) / \mathrm{Ca}(2+)$ exchanger NCKX4 governs termination and adaptation of the mammalian olfactory response. Nat Neurosci 15:131-137. CrossRef Medline

Torre V, Ashmore JF, Lamb TD, Menini A (1995) Transduction and adaptation in sensory receptor cells. J Neurosci 15:7757-7768. Medline

Trotier D (1994) Intensity coding in olfactory receptor cells. Semin Cell Biol 5:47-54. CrossRef Medline

Trotier D, MacLeod P (1983) Intracellular recordings from salamander olfactory receptor cells. Brain Res 268:225-237. CrossRef Medline

Vocke K, Dauner K, Hahn A, Ulbrich A, Broecker J, Keller S, Frings S,
Möhrlen F (2013) Calmodulin-dependent activation and inactivation of anoctamin calcium-gated chloride channels. J Gen Physiol 142:381404. CrossRef Medline

Wayman GA, Impey S, Storm DR (1995) $\mathrm{Ca}^{2+}$ inhibition of type III adenylyl cyclase in vivo. J Biol Chem 270:21480-21486. CrossRef Medline

Wei J, Wayman G, Storm DR (1996) Phosphorylation and inhibition of type III adenylyl cyclase by calmodulin-dependent protein kinase II in vivo. J Biol Chem 271:24231-24235. CrossRef Medline

Wei J, Zhao AZ, Chan GC, Baker LP, Impey S, Beavo JA, Storm DR (1998) Phosphorylation and inhibition of olfactory adenylyl cyclase by CaM kinase II in Neurons: a mechanism for attenuation of olfactory signals. Neuron 21:495-504. CrossRef Medline

Yan C, Zhao AZ, Bentley JK, Loughney K, Ferguson K, Beavo JA (1995) Molecular cloning and characterization of a calmodulin-dependent phosphodiesterase enriched in olfactory sensory neurons. Proc Natl Acad Sci U S A 92:9677-9681. CrossRef Medline

Zufall F, Leinders-Zufall T (2000) The cellular and molecular basis of odor adaptation. Chem Senses 25:473-481. CrossRef Medline 